\title{
OS EMPREGOS SUBALTERNOS NO SETOR DE TELECOMUNICAÇÕES: COMPARAÇÕES FRANÇA-ALEMANHA
}

\author{
ISABEL PAULINE HILDEGARD GEORGES
}

FAPESP - Fundação de Amparo à Pesquisa do Estado de São Paulo

CEBRAP - Centro Brasileiro de Análise e Planejamento

Resumo: Este artigo trata das transformações da atividade feminina, na França e na Alemanha, a partir dos anos 1960, com base em uma análise de empregos subalternos no setor público. 0 estatuto da atividade feminina se diferencia entre os dois países europeus, conquanto algumas similitudes possam ser igualmente reconhecidas. Assim, na Alemanha, ao contrário da França, as mulheres que não trabalham de maneira contínua distinguem-se das que têm uma carreira contínua tanto por sua situação conjugal, como pelo fato de terem filhos. A partir dessa constatação geral, analiso a influência da gestão do trabalho no setor público, nos diferentes países, sobre as normas e as práticas das mulheres ali ocupadas. Analisarei o papel social que cumpre um tipo particular de emprego, o das telefonistas do serviço de auxílio à lista, considerado aqui como protótipo de trabalho assalariado pouco qualificado, reunindo evidências de tipo qualitativo, para discutir as relações que essas trabalhadoras estabelecem com o trabalho e com o emprego.

Palavras-chave: trabalho de mulheres, trabalho subalterno, setor público, comparação FrançaAlemanha.

Com base em uma comparação entre a França e as duas Alemanhas (Ocidental e Oriental), ${ }^{1}$ este artigo trata do impacto dos empregos do serviço público nas transformações do comportamento de atividade das mulheres nos três países desde os anos 1960, tanto do ponto de vista institucional quanto das práticas individuais e coletivas. ${ }^{2}$ O argumento é construído da seguinte forma: com base em uma apresentação geral em

\footnotetext{
Copyright $\odot 2004$ by Revista Estudos Feministas

' Embora nossa idéia inicial tenha sido de uma comparação França-Alemanha, desde logo ficou claro que as duas partes da Alemanha continuam a constituir, apesar da reunificação de 1989, duas entitades distintas em termos de práticas sociais, o que alguns denominaram de "efeito societal" (Marc MAURICE, François SELLIER e Jean-Jacques SILVESTRE, 1982).

Este artigo foi extraído de uma tese de Sociologia (Isabel GEORGES, 2000a) e vai ser publicado em 2005 pela Éditions L'Harmattan, Collection Logiques Sociales. A análise das trajetórias foi sistematizada em uma versão anterior, adaptada para o público francês (cf. Isabel GEORGES, 2001). Agradecemos em particular, entre outros, aos membros da comissão editorial Revista Estudos Feministas que coordenaram o presente número, bem como aos colaboradores externos por suas observações e sugestões construtivas.

${ }^{2}$ Este estudo se beneficiou, em 1996-1999, de uma convenção Cifre (Convention industrielle de formation par la recherche) com a France Télécom, no âmbito da minha tese.
} 
termos de condições de acesso aos empregos subalternos do serviço público, ele tratará de construir uma classificação dos diferentes grupos de trajetórias sociais e profissionais, distinguindo as que se desenrolam no mesmo nível hierárquico e nos ascendentes. A análise comparativa das entrevistas sobre a trajetória profissional ressaltará a importância do status matrimonial.

Desde os anos 1960, o comportamento da atividade das mulheres na França e na Alemanha sofreu uma transformação fundamental: a atividade contínua tornou-se regra. ${ }^{3}$ Na França, esse é sobretudo o caso das mulheres casadas (ou que vivem maritalmente) e com filhos. Em contrapartida, na Alemanha, o status matrimonial $e$ o fato de se ter filhos refletem a separação entre as mulheres que possuem uma atividade contínua e aquelas que estão integradas parcialmente no mercado de trabalho, como mostraram recentes trabalhos de avaliação quantitativa. ${ }^{4}$

Este artigo pretende analisar como esses empregos do serviço público contribuem para essa dinâmica. Mais particularmente, estudo o papel de um trabalho feminino assalariado considerado pouco qualificado, partindo de uma análise qualitativa das relações com o trabalho e o emprego de um subgrupo da categoria socioprofissional das operadoras dos serviços de informações telefônicas na França e na Alemanha. ${ }^{5}$ Como explicar a fixação duradoura, mas desigual entre esses países, das mulheres no mundo do trabalho assalariado desde o final dos anos 1960 pelo estudo desses empregos terciários do serviço público? Em que medida o status desses empregos e a utilização que as mulheres fazem deles favorecem a sua inserção? Que sentido adquire a atividade profissional do ponto de vista das mulheres? Ou seja, como a concepção que elas possuem acerca da sua atividade profissional, e da atividade extraprofissional, contribui para criar ou deslocar as normas do comportamento de atividade das mulheres nos dois países (ou melhor, nos três, com a ex-RDA)? Pretendo analisar a disposição dessas novas normas no âmbito de uma atividade particular, no cruzamento de um estudo sobre a mobilidade social (das mulheres, mas também de seus cônjuges), da sociologia da família e da sociologia do trabalho. Como Margaret Maruani, distingo na análise o trabalho, definido como "a atividade de produção de bens e serviços e o conjunto de condições para o exercício dessa atividade", e o emprego, entendido como "as modalidades de acesso ao mercado de trabalho e a tradução da atividade laboriosa em termos de status sociais". 6 Estudo o meio socioprofissional dos empregos não técnicos, de status inferior, da operadora francesa de telecomunicações, que deteve o monopólio sobre o telefone até há pouco, e a atividade dessas mulheres. ${ }^{7}$

Interessei-me pelo grupo mais estável: a escolha das operadoras em 'fim de carreira', assim como de algumas 'jovens', e exclui todas aquelas que possam ter galgado os degraus hierárquicos dentro ou fora da administração do Correio, Telégrafo e Telecomunicações (P.T.T. - Postes, Télégraphes et Télécommunications) e aquelas que se readaptaram ou se tornaram inativas. Elas fazem parte da primeira geração de mulheres, na França, com trajetórias de atividade contínuas. ${ }^{8}$ Após ingressarem no mercado de trabalho no final dos anos 1960 e no início dos anos 1970, elas passaram toda a sua vida ativa na administração dos P.T.T. As mulheres que realizaram uma carreira profissional,

\footnotetext{
${ }^{3}$ Margaret MARUANI, 2000.

${ }^{4}$ Catherine MARRY, Annick KIEFFER e Hildegard BRAUNS, 1998.

${ }^{5}$ GEORGES, 2000a.

${ }^{6}$ MARUANI, 1989 e 1993. As relações do trabalho, assim como da produtividade, ficam na periferia da análise neste artigo, por falta de espaço. Cf. GEORGES, 2000b.

7 Um estudo com um método similar já foi realizado com bancários por Yves Grafmeyer, 1990 e 1992.

${ }^{8}$ Françoise BATTAGLIOLA, 2000, p. 82-83.
} 
assim como aquelas que se caracterizam por uma relação de trabalho instável, não constituem, portanto, o interesse principal deste estudo. Quis analisar uma variedade significativa de casos (homens e mulheres, velhos e jovens, de origens sociais, regionais e étnicas diferentes) e mostrar de que maneira eles constroem sua relação com o trabalho e o emprego. Esse panorama não tem, por isso mesmo, a ambição de ser exaustivo, representativo do pessoal dos P.T.T., e menos ainda do serviço público, mas tenta jogar uma luz sobre como uma determinada categoria de mulheres transforma suas normas em matéria de comportamento de atividade no espaço de apenas uma geração.

\begin{abstract}
Elaborei uma monografia sobre a operadora de telefone na França, desde o final dos anos 1960 até a época atual, dentro de uma perspectiva comparativa. A problemática dessa pesquisa é, em primeiro lugar, proveniente da confrontação de dados empíricos variados, que tratam de uma perspectiva histórica relativamente longa, e da comparação com o caso alemão (da história institucional e das trajetórias socioprofissionais). Foi preciso considerar não apenas o ponto de vista das operadoras sobre sua atividade, mas também o daqueles da chefia intermediária e dos gestores, que se condicionam reciprocamente. Entrevistei as operadoras por meio de entrevistas semi-dirigidas (cerca de 30 por país, 66 no total), realizadas no local de trabalho, tratando da trajetória socioprofissional, e também pela observação participante em vários centros de informações telefônicas (na França, em Paris, na região parisiense e no interior (7), assim como em três centros de informações situados no mesmo nicho de empregos e parcialmente terceirizados); na Alemanha, em Berlin, nos antigos Länder industriais do norte da Alemanha e em um dos novos Länder, em uma zona rural (6), realizei entrevistas sobre a trajetória profissional, nos locais de trabalho, com operadoras de telefone e com a chefia. Usei, também, documentos de arquivo. Na França, onde ocupei a função de gerente junior (R\&D) durante três anos em uma equipe de gestores do serviço de auxílio à lista em Paris, a fim de realizar minha tese de Sociologia, minha origem estrangeira (alemã) facilitoume o acesso aos diferentes centros locais (negociado diretamente e individualmente) e o estabelecimento de uma relação de confiança com o pessoal de execução. Por outro lado, sendo da mesma idade dos filhos dos/as funcionários/as públicos/as que trabalhavam nos centros durante as férias escolares, freqüentemente ocupei o papel de aprendiz. Na Alemanha, apresenteime à empresa como estudante de Sociologia realizando uma tese. Mantive contato com informantes variados (sindicalistas, gestores da empresa alemã, as encarregadas da igualdade de homens e mulheres etc.).
\end{abstract}

De fato, o contexto francês atual caracteriza-se por uma situação em que "o modelo dominante não é mais aquele da escolha (trabalho ou família); não é mais o da alternância (trabalhar, parar, trabalhar novamente), mas aquele do acúmulo. A taxa de atividade das mulheres de 25 a 49 anos é de $80 \%$, enquanto não passava de $40 \%$ nos anos $1960 " .{ }^{9} \mathrm{Em}$ contrapartida, na República Federal da Alemanha (RFA), ainda não se chegou a isso: no início dos anos 1990, embora a taxa de atividade das mulheres de menos de 45 anos fosse de $61,7 \%$, a taxa das mulheres com filhos de menos de 18 anos era de somente $51,9 \% .{ }^{10}$ Como conclui Catherine Marry, "assim, em 1991, a figura dominante da mulher ativa na França é a da mulher casada e mãe de família (51,6\% dos ativos); na Alemanha é a da mulher solteira ou casada, sem filhos $(55,2 \%)$ ". ${ }^{11}$ A curva bimodal da atividade

\footnotetext{
${ }^{9}$ Cf. MARUANI, 2000.

${ }^{10} \mathrm{Cf}$. Arbeitsmarktreport für Frauen, 1994, p. 18 (fonte: Mikrozensus 1991).

${ }^{11}$ Cf. MARRY et al., 1998, p. 369 (fontes: Enquête Emploi, Mikrozensus 1991).
} 
feminina, ou da atividade descontínua, ou seja, das mulheres que param de trabalhar no momento da educação dos filhos (e retomam muitas vezes em meio período) ainda existe, contrariamente à França, onde, a partir dos anos 1960, o período de interrupção do trabalho das mulheres passou do momento do primeiro para o do terceiro filho. A continuidade da atividade profissional tornou-se a norma. Na ex-RDA, a atividade contínua das mulheres era também a regra (em 1989, 85\% de todas as mulheres entre 15 e 60 anos eram ativas, comparadas com $55 \%$ das mulheres na RFA). A maioria delas tinha pelo menos um filho $(90 \%) .^{12}$

A partir da comparação das duas (três) populações, abordo a construção da relação de emprego das mulheres sob três ângulos. A mobilidade social é abordada com base na relação das mulheres com suas carreiras, mas também com a de seus companheiros e com o tipo de união matrimonial. ${ }^{13}$ Essa abordagem leva em conta a sociologia da família em relação ao comportamento matrimonial, a divisão dos papéis entre o casal e a influência do nascimento dos filhos. Um terceiro eixo, consagrado à sociologia do trabalho, aborda as diferenças de estatuto, ${ }^{14}$ os modos de recrutamento ${ }^{15}$ e as condições de trabalho, mas sobretudo as vantagens que o status do emprego - isto é, os benefícios salariais vinculados ao emprego assim como o seu valor social - proporciona às mulheres.

Daí decorre uma certa concepção da atividade que repousa na questão da pertinência da distinção entre o universo profissional e extraprofissional do ponto de vista das mulheres. A idéia inicial é de que as mulheres podem, em uma certa medida, modificar as condições de exercício de sua atividade nesses empregos de status inferior na França, contrariamente à Alemanha do final dos anos 1960 e até os anos 1980: elas contribuem para a construção social da atividade. As empregadas francesas possuem uma margem relativamente grande de negociação informal das condições de exercício da atividade. Por exemplo, sob a condição de dar pouca importância ao conteúdo do trabalho, elas podem, no limite de um emprego disponível, escolher sua localização geográfica. Mas também no interior de um mesmo país, ou seja, nas duas partes da Alemanha, o sentido desse emprego difere fundamentalmente aos olhos das mulheres: nos antigos Länder, o estatuto do emprego, diferentemente dos empregos situados no setor privado, permitia notadamente que se parasse de trabalhar sem perda da garantia de emprego. Nos novos Länder essa característica constituía a regra. Empregos pouco prestigiados como esses, em razão de seu caráter 'não produtivo', estavam sempre disponíveis. Assim, a comparação das vantagens relativas desses empregos aos olhos das mulheres nos dois (três) países demonstra a sua particularidade em relação ao setor privado, assim como essas características podem permitir às mulheres novas práticas em matéria do comportamento de atividade, como a norma da atividade contínua na França.

O artigo comporta quatro partes: uma apresentação sucinta do setor das telecomunicações na França e na Alemanha, na primeira parte; as diferentes modalidades de acesso a esses empregos de status inferior e suas implicações, na segunda; os modos de utilização, pelas mulheres, dessas condições institucionais, na terceira; e, por fim, a conclusão acerca do papel social desses empregos dentro dos diferentes contextos societais.

\footnotetext{
${ }^{12}$ Cf. Sigrid QUACK e Friederike MAIER, 1994, p. 1260.

${ }^{13}$ Sabendo-se que a sociedade alemã é conhecida, de uma maneira geral, pela característica de apresentar menores distâncias sociais que a França.

${ }^{14} \mathrm{Na}$ Alemanha, por exemplo, ao contrário da França, uma fração significativa das operadoras possuem o estatuto empregados/as administrativos/as (Angestellte), sem serem estatutários/as.

${ }^{15}$ O recrutamento do serviço público é local na Alemanha; na França ele é regido pelo princípio do concurso, associado à mobilidade geográfica.
} 


\section{O setor das telecomunicações na França e na Alemanha}

A comparação dos efetivos a serviço do Estado na França e na Alemanha (Quadro I) demonstra um peso numérico similar. Em contrapartida, além do seu peso desigual na população ativa na França, a proporção dos assalariados diretamente ao Estado é comparativamente muito mais significativa na França do que na Alemanha, onde os assalariados estatais das unidades regionais (Länder) e locais (Gemeinden) são largamente majoritários, o que se explica pelo escasso peso histórico do aparelho estatal central. A construção constitucional da República Federal da Alemanha, no pós-guerra, dá um peso e autonomia (por exemplo, em matéria de educação) muito mais importante às regiões, até mesmo ao poder local, histórica e economicamente um dos motores da economia nacional, e nisso se diferencia da França.

QUADRO I - O PESO DO SETOR PÚBLICO NA FRANÇA E NA ALEMANHA

\begin{tabular}{l|l|l}
\hline & França & Alemanha \\
\hline Assalariados do Estado/Bund & 1.736 .489 & 510.200 \\
Assalariados das coletividades & & \\
territoriais /Länder, Gemeinden & 3.197 .212 & 3.923 .400 \\
Outros $^{16}$ & - & 346.000 \\
Total $_{\text {População ativa (total) }}$ & 4.933 .701 & 4.779 .600 \\
& 26.457 .000 & 37.942 .000
\end{tabular}

FONTE: Enquête Emploi de janvier 1999, INSEE; Statistisches Bundesamt, Personal des öffentlichen Dienstes, juin 1999

GRÁFICO I - O PESSOAL DA ADMINISTRAÇÃO DOS CORREIOS, TELÉGRAFOS E TELECOMUNICAÇÕES NA FRANÇA E ALEMANHA POR ESTATUTO

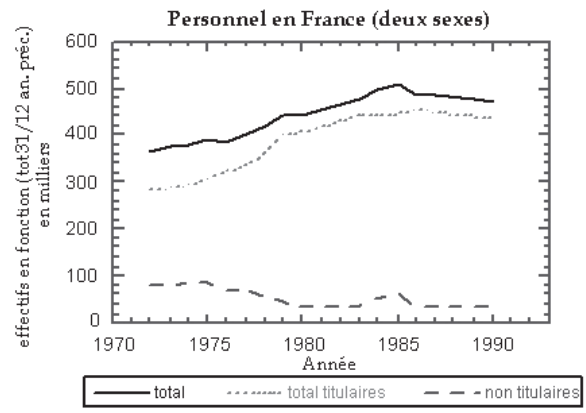

Na França, ${ }^{17}$ a parte dos estatutários/as é predominante até o início do período das privatizações, com a mudança de estatuto da administração dos correios e das telecomunicações, que se tornou 'explorador público', e a cisão entre suas duas entidades.

\footnotetext{
${ }^{16}$ A categoria "outros" comporta o conjunto dos assalariados alemães que não possuem estatuto permanente (Beamte ou Angestellte), como os trabalhadores sazonais e/ou ocasionais, mas também os assalariados que não estão diretamente vinculados a uma das unidades da administração estatal.

${ }^{17} \mathrm{Na}$ França, a parte referente ao pessoal não-titular não figura nas estatísticas do ministério dos P.T.T. Ela foi obtida pela subtração do pessoal titular do total do pessoal na função.
} 


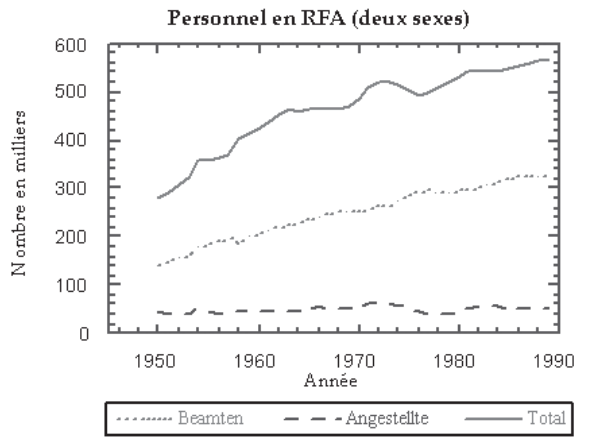

Na Alemanha, os funcionários públicos estatutários (Beamte) representam apenas cerca da metade do pessoal, enquanto os outros ocupam o estatuto de empregados/as (Angestellte), reservado sobretudo às mulheres.

FONTES: Relatórios anuais de France Télécom e de Deułsche Telekom, Arquivos Internos

Comparando-se o pessoal da administração, na França e na Alemanha, segundo o tipo de estatuto, vemos que há atualmente uma estabilidade profissional maior entre os assalariados franceses, situação similar à que prevaleceu na Alemanha até o início da privatização dos correios e das telecomunicações, em 1989, e às mudanças nas convenções coletivas relativas à situação efetiva dos Beamte (estatutários) e dos Angestellte (empregados administrativos). ${ }^{18}$

GRÁFICO 2 - COMPARAÇÃO ENTRE A PROPORÇÃO DE EMPREGADAS ADMINISTRATIVAS ESTATUTÁRIAS FEMININAS DA ADMINISTRAÇÃO DOS CORREIOS, TELÉGRAFOS E TELECOMUNICAÇÕES NA FRANÇA E NA ALEMANHA

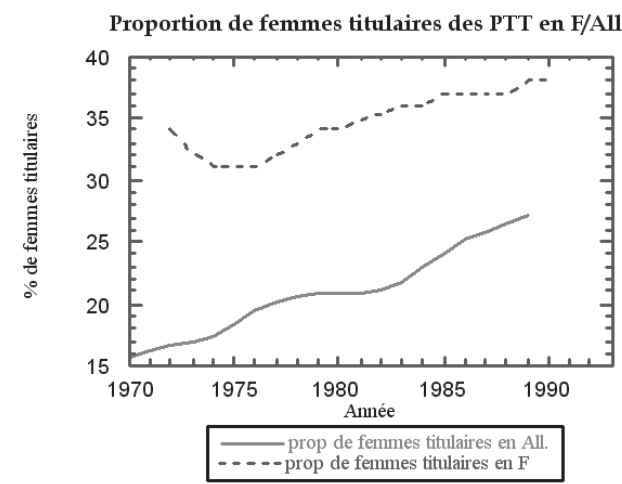

FONTES: Relatórios anuais de France Télécom e de Deutsche Telekom, Arquivos Internos

A comparação da parte referente às empregadas estatutárias em relação ao total dos estatutários da administração dos P.T.T. dos dois sexos, na França e na Alemanha, confirma os resultados do gráfico precedente: o peso das empregadas estatutárias

\footnotetext{
${ }^{18}$ As diferenças referiam-se notadamente ao modo de contribuição para a aposentadoria, e seu montante (proporção do salário mais significativa para os funcionários), assim como ao nível salarial no início de carreira (mais elevado para os empregados) e à rapidez de aumento (o aumento indicial dos funcionários, o que permitia uma recuperação do salário dos empregados). Em contrapartida, a proporção de titulares e de empregados varia muito entre o interior e os centros urbanos alemães (proporção de titulares mais significativa no interior), notadamente para as mulheres.
} 
francesas é mais significativo que o das alemãs. Em contrapartida, o número das estatutárias alemãs aumenta muito mais rapidamente, tendo em vista o baixo nível inicial.

GRÁFICO 3 - O PESSOAL DA DEUTSCHE POST (CORREIO DA EX-RDA) POR SEXO

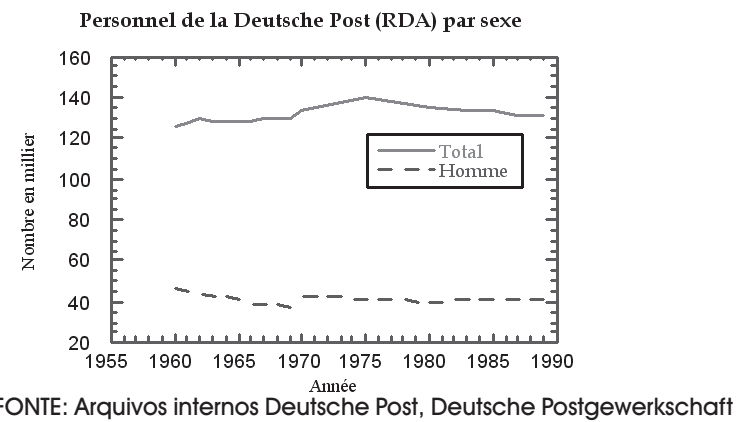

Na RDA, em um contexto societal muito diferente, a totalidade dos trabalhadores (sem distinção entre o privado e o público) dispunha de um estatuto estável. A particularidade do pessoal dos correios era a fraca presença de homens, notadamente em razão da pouca atração exercida por essas atividades, consideradas pouco produtivas (um valor central na Alemanha do Leste) e sem prestígio.

O serviço de auxílio à lista era uma das atividades femininas situadas no nível baixo da escala de classificações dos P.T.T. na França. Esses empregos constituíam o início da carreira do serviço geral não-técnico. Difundidas por todo o território ${ }^{19}$ no início dos anos 1970 , quando da automatização do telefone, as informações eram dadas primeiramente de forma suplementar, pelas operadoras da comutação manual. As operadoras de telefone eram recrutadas por concursos que aferiam conhecimentos gerais. ${ }^{20}$ Sem atribuição precisa, elas tinham acesso a uma infinidade de empregos, como o atendimento no guichê do correio, os centros de tratamento dos cheques postais, os serviços de perfuração de cartões e as informações. Essas atividades heterogêneas se caracterizam por uma fraca mobilidade hierárquica, mas por uma forte mobilidade horizontal. No serviço de auxílio à lista, não era raro que as operadoras fossem efetivadas, como estatutárias, após um período mais ou menos prolongado como auxiliares. Elas não contavam com treinamento específico e aprendiam a atividade no local de trabalho. No final dos anos 1990, o serviço continua sendo executado por operadoras estatutárias $(90 \%)$. A grande maioria era mulheres $(70 \%$ - razão pela qual o termo "operadora" é utilizado de forma genérica). Contudo, desde a reforma dos estatutos de $1990,{ }^{21}$ as operadoras no serviço de informações passaram a ser recrutadas e designadas para esse posto. Essa mudança foi acompanhada de uma transformação dos modos de gestão das carreiras dos agentes.

\footnotetext{
19 O primeiro centro de serviço de auxílio à lista é o centro Paris-Anjou, inaugurado em 1938.

${ }^{20}$ As operadoras de telefone tinham, na maior parte do tempo, o estatuto de agent d'exploitation - AEX (escriturário estatutário), pertencente aos níveis $D$ e $C$ (por promoção por antiguidade) no plano de classificação de cargos do serviço público (que vai da letra A à letra D, em ordem decrescente). Em 1993, quando da reclassificação dos cargos, esse cargo era classificado como de nível 1.3 (em uma escala que, em ordem crescente, ia até 4).

${ }^{21}$ Para uma apresentação da reforma, ver Emmanuèle REYNAUD, Jean-Daniel REYNAUD e Nicole MERCIER, 1991; e Norbert ALTER e Emmanuèle REYNAUD, 1995.
} 
Na França, essa antiga mão-de-obra residual, dos agentes escriturários femininos destituídos quando da automatização do telefone no final dos anos 1960 e redesignados em parte para os centros de informações telefônicas, atravessou um longo período de automatização. Fadada ao desaparecimento com a generalização do anuário eletrônico nos anos 1980, essa categoria se beneficia atualmente de uma conjuntura extremamente favorável, com o ressurgimento das centrais de atendimento. ${ }^{22} \mathrm{Em}$ contrapartida, a empresa alemã de telecomunicações reduziu os efetivos de seu serviço de auxílio à lista. ${ }^{23}$

\section{Concurso de circunstâncias ou estrágia feminina? A entrada nos Correios, Telégrafos e Comunicações}

A comparação entre a França e a Alemanha mostra uma similitude inicial dos meios socioprofissionais de origem das futuras operadoras: na maioria, provêm de camadas médias inferiores do setor público e privado e, em alguns casos, são moças de origem operária ou camponesa. Entretanto, as modalidades de acesso a esses empregos, ou seja, a relação entre o diploma, a origem social e geográfica e o tipo de ingresso na administração, divergem de um país para outro (Quadros 2, 3 e 4). De uma maneira geral, a maioria das operadoras entrevistadas encontrava-se no final da sua trajetória profissional (cerca de dois terços das entrevistas realizadas por país, critério de seleção da amostra que indiquei aos responsáveis dos centros locais na fase inicial da pesquisa), comparadas com um pequeno grupo de jovens. Nos dois países, encontrei um certo número de famílias monoparentais. ${ }^{24} \mathrm{Em}$ compensação, somente na amostra francesa havia famílias numerosas. ${ }^{25}$ É também nesse país que a quase totalidade das operadoras são casadas ou vivem maritalmente no final de sua vida profissional, contrariamente à Alemanha.

\footnotetext{
${ }^{22}$ Trata-se de um movimento de amplitude internacional que consiste em transferir diversas atividades, na maioria dos serviços prestados primeiramente em interação direta, para os serviços por telefone. Essa transformação geral da divisão do trabalho com o consumidor, favorecida pelas novas capacidades de transmissão de dados da rede telefônica (digital e, mais recentemente, a transmissão via satélite), leva a uma multiplicação dos empregos situados nas diversas centrais de atendimento (serviços financeiros, vendas por telefone, serviços ao consumidor, tecnologias e telecomunicações etc.), como comprova a multiplicação de literatura sobre o tema, como, por exemplo, na França, Marie BUSCATTO, 2002; Olivier COUSIN, 2002; e Patrice FLICHY e Philippe ZARIFIAN, 2002.

${ }^{23}$ As empresas concorrentes subtraem essa atividade, com exceção de uma empresa especializada (Telegate, assim como a Viag Intercom et Talkline). Cf. Handelsblatt, 1999, p. 23.

${ }^{24}$ Entre as três pessoas oriundas de famílias monoparentais da amostra francesa (ou seja, que cresceram sem o pai e com uma mãe ativa), duas mães eram empregadas nos P.T.T., uma era recepcionista em uma agência de correio em Landes, a outra era operadora manual na região parisiense. A terceira era trabalhadora na Alcatel, na região parisiense, como sua filha, antes do fechamento da usina e de seu ingresso tardio no serviço de auxílio à lista da empresa.

${ }^{25}$ Dez pessoas da população entrevistada na França são oriundas de famílias numerosas, originárias dos meios operários do norte da França (5), mas também do Oeste, dos DOM-TOM (meios rurais) e do centro.
} 
QUADRO 2 - ORIGEM SOCIOPROFISSIONAL DO CHEFE DA CASA DA POPULAÇÃO ENTREVISTADA NA FRANÇA

\begin{tabular}{l|c}
\hline Categorias socioprofissionais (PCS) & Número \\
\hline 1 Agricultores & 6 \\
2 Artesãos, comerciantes e chefes de empresa & 5 \\
3 Quadros e profissões intelectuais superiores & 3 \\
4 Profissões intermediárias & 3 \\
5 Empregados & 4 \\
6 Operários & 6 \\
Sem resposta & 6 \\
Total & 33 \\
\hline
\end{tabular}

FONTE: Trabalho de campo, França

QUADRO 3 - ORIGEM SOCIOPROFISSIONAL DA POPULAÇÃO ENTREVISTADA NA FRANÇA SEGUNDO O MEIO (PRIVADO/PÚBLICO) E A REGIÃO GEOGRÁFICA

\begin{tabular}{|c|c|c|c|}
\hline Origem socioprofissional & & \multicolumn{2}{|c|}{ Origem geográfica (região) } \\
\hline \multicolumn{4}{|l|}{ Tpólo } \\
\hline \multirow[t]{3}{*}{ Agricultores } & 6 & Sudoeste & 3 \\
\hline & & DOM-TOM ${ }^{26}$ & 2 \\
\hline & & Centro & 1 \\
\hline \multirow[t]{2}{*}{ Artesãos } & 4 & Centro & 3 \\
\hline & & Sudoeste & 1 \\
\hline \multirow[t]{3}{*}{ Meio operário } & 6 & Oeste & 3 \\
\hline & & lle-de-France & 2 \\
\hline & & Leste & 1 \\
\hline \multirow{6}{*}{$\begin{array}{l}2^{\circ} \text { pólo } \\
\text { Operários, empregados, } \\
\text { profissões intermediárias } \\
\text { e chefia (público) }\end{array}$} & 11 & Sudoeste & 4 \\
\hline & & Oeste & 3 \\
\hline & & Centro & 1 \\
\hline & & DOM-TOM & 1 \\
\hline & & Norte & 1 \\
\hline & & lle-de-France & 1 \\
\hline \multirow{3}{*}{$\begin{array}{l}\text { Sem resposta } \\
\text { Total }\end{array}$} & & & 27 \\
\hline & & & 6 \\
\hline & & & 33 \\
\hline
\end{tabular}

FONTE: Trabalho de campo, França

${ }^{26}$ Départements et Territoires d'Outre-Mer. 
QUADRO 4 - ORIGEM SOCIAL E NIVEL DE FORMAÇÃO DA POPULAÇÃO ENTREVISTADA NA ALEMANHA OCIDENTAL E NA ORIENTAL, NO INTERIOR E NOS CENTROS URBANOS

\begin{tabular}{|c|c|c|c|c|}
\hline & \multicolumn{2}{|c|}{$\begin{array}{l}\text { Alemanha } \\
\text { Ocidental (antigos Länder) }\end{array}$} & \multicolumn{2}{|c|}{$\begin{array}{l}\text { Alemanha } \\
\text { Oriental (novos Länder) }\end{array}$} \\
\hline & Interior & Cidade & Interior & Cidade \\
\hline $\begin{array}{l}\text { Geral pop. } \\
\text { centros }\end{array}$ & 2/3 estatutários & '1/3 estatutários & $\begin{array}{l}100 \% \\
\text { estatutários }\end{array}$ & $\begin{array}{l}100 \% \\
\text { estatutários }\end{array}$ \\
\hline Origem socia & $\begin{array}{l}\text { Origem } \\
\text { relativamente } \\
\text { mais elevada, } \\
\text { filhas de notáveis } \\
\text { locais, como } \\
\text { sejam diretor de } \\
\text { escola (1), de } \\
\text { uma fiação (2); } \\
\text { fração inferior da } \\
\text { função } \\
\text { pública (1), } \\
\text { artesão (1), } \\
\text { agricultor (1) }\end{array}$ & $\begin{array}{l}\text { Frações inferiores } \\
\text { da função } \\
\text { pública(4), } \\
\text { empregados, } \\
\text { qualificados (2), } \\
\text { artesãos (2), } \\
\text { pequeno } \\
\text { empresário (1) }\end{array}$ & $\begin{array}{l}\text { Frações inferiores } \\
\text { da administração } \\
\text { (3, dos quais } 2 \\
\text { ferroviários e } 1, \\
\text { policial), } \\
\text { artesãos (2, } \\
\text { dos quais } 1 \\
\text { pintor e } 1 \\
\text { caminhoneiro), } \\
\text { operários (2), } \\
\text { agricultores (2) }\end{array}$ & $\begin{array}{l}\text { Fração inferior } \\
\text { da administração } \\
\text { (1 agente de polícia) } \\
\text { empregados } \\
\text { (3, dos quais } 1 \\
\text { contador, } 1 \\
\text { Angestellter e } 1 \\
\text { caixa), } 1 \\
\text { artesãos (4) }\end{array}$ \\
\hline Formação & $\begin{array}{l}\text { Mittlere Reife (10 } \\
\text { anos de escola } \\
\text { nível médio) (6) }\end{array}$ & $\begin{array}{l}\text { Hochschulreife } \\
\text { (13 anos de } \\
\text { escolaridade) (1), } \\
\text { Mittlere Reife (5), } \\
\text { Polytechnische } \\
\text { Oberschule (10 } \\
\text { anos de } \\
\text { escolaridade) (1) } \\
\text { e Haupt- und } \\
\text { Volksschule (8 } \\
\text { anos de } \\
\text { escolaridade) (2) }\end{array}$ & $\begin{array}{l}\text { Volksschule } \\
\text { (8 anos) (4), } \\
\text { Polytechnische } \\
\text { Oberschule (10 } \\
\text { anos) (5) }\end{array}$ & $\begin{array}{l}\text { Abitur (12 anos } \\
\text { de escolaridade) } \\
\text { (1),Volksschule } \\
\text { (4) e Polytechnische } \\
\text { Oberschule } \\
\text { (10 anos) (4) }\end{array}$ \\
\hline
\end{tabular}

FONTES: Trabalho de campo, Alemanha

As jovens mulheres possuíam um nível escolar relativamente elevado para a época (na França, pelo menos o BEPC - Brevet d'Études du Premier Cycle - equivalente a oito anos de estudos), mas muitas chegavam até o último ano dos estudos secundários (o ano que precede o baccalauréat, que sanciona o êxito nos estudos secundários, equivalente a 11 anos de estudos), na Alemanha a Mittlere Reife (dez anos de estudos). Há casos de reconversão em ambos os países, mas somente na França existem operadoras mais diplomadas que a média, que hesitam e ingressam muito tardiamente na função pública.

Na França, o acesso aos empregos administrativos requer a aprovação em concurso para agente escriturário de serviços gerais. De fato, conforme o estatuto geral do serviço público francês, de 1946, a aprovação no concurso importa em mobilidade geográfica. Entretanto, a partir do final dos anos 1950, flexibilizam-se as exigências da administração em face das candidatas ao concurso pelo primeiro nível de empregado administrativo 
público, os agentes escriturários femininos. A administração passou a exercer um controle mais fraco sobre a qualificação de seus agentes (sancionada, em um primeiro momento, pelo diploma requerido para a apresentação no $\operatorname{concurso}^{27} \mathrm{e}, \mathrm{em}$ um segundo momento, pela aprovação).

Os critérios mais frouxos de recrutamento conferem, então, maior importância à prática dos agentes. O prestígio desses empregos era bem menor durante os anos 1960, de relativa escassez de mão-de-obra. Sendo raramente uma verdadeira escolha profissional, o ingresso nesses empregos administrativos, assim como a sua aprendizagem, fazia-se progressivamente, passando por diversos estatutos, mesmo para aqueles que referem a sua entrada nos P.T.T. como uma "escolha profissional" relativa. Os agentes aceitam manter $\mathrm{o}$ estatuto de auxiliar por um período mais ou menos prolongado em troca de uma derrogação da regra da mobilidade geográfica (ligada ao concurso).

A maioria das mulheres teve acesso a esses empregos após haverem exercido outras funções, e/ou tardiamente, sem passar por concurso de ingresso. $O$ acesso a uma certa estabilidade socioprofissional e ao status social a ela correlata constituem uma oportunidade, notadamente para as pessoas advindas das camadas populares (meio operário ${ }^{28}$ e de famílias numerosas, com cinco filhos ou mais (10), e também para algumas operadoras que cresceram em famílias monoparentais (3) ou sem os pais (uma pessoa é órfã e uma outra foi colocada em uma casa de correção). Em alguns casos, as mulheres encontram-se sozinhas para assumir a renda do lar após uma ruptura familiar. Para essas mulheres, as condições de exercício da atividade adquirem toda a importância, especialmente se comparadas com outros empregos de execução menos estáveis (de vendedora, por exemplo) e com condições de trabalho menos vantajosas. O ingresso na administração também representava, aos seus olhos, o acesso a um mercado interno de trabalho, portador de outras possibilidades futuras. Como os demais empregos administrativos, os empregos dos P.T.T. exercem igualmente uma certa atração sobre as pessoas originárias dos DOM (Départements Outre-Mer). Os raros candidatos ao concurso de AEX (agent d'exploitation féminin - agente escriturário feminino) são, em sua maioria, alunas que não conseguiram chegar ao baccalauréat (o que lhes teria permitido concorrer diretamente ao nível B), embora um nível próximo do segundo grau completo (equivalente a 11 anos de estudos) não seja raro. Por certo, trata-se de uma alternativa que é considerada com freqüência apenas após o fracasso em outras opções consideradas melhores - a École Normale d'Institutrices, no melhor dos casos. Mas esse trabalho de escritório goza, sem dúvida, de maior prestígio social que, por exemplo, o trabalho agrícola.

\footnotetext{
${ }^{27}$ O BEPC (Brevet d'Études de Premier Cycle) à época, criado em 1974, para substituir o BEPS (Brevet d'Études Primaires Supérieures). Esse diploma equivale a oito anos de estudos, e geralmente preparava para 0 aprendizado de um ofício. Desde 1959 (leis Debré - escolaridade obrigatória até 16 anos), o sistema de ensino público francês é composto de três ciclos: todos os alunos freqüentam a escola pública sem distinção (com exceção do privado, cujo peso crescente atinge $20 \%$ em 2004), os quatro anos da École Primaire e os quatro anos do primeiro ciclo do segundo grau (o ensino secundário da $6^{a}$ à $3^{a}$ ) nos CES (Collège d'Enseignement Secondaire). A admissão em uma escola ocorre em função do local de residência. A seguir, os alunos podem optar por um ciclo longo no lycée (áreas literárias, científicas ou técnicas, sendo as científicas as mais valorizadas), como preparação para as classes preparatórias para as Grandes Écoles (a mais prestigiosa é a ENA - l'École Nationale d'Administration, que prepara para a carreira política), assim como para o acesso às universidades públicas ou para um ciclo curto (industrial, comercial ou administrativo), que prepara para o CAP (Certificat d'Aptitude Professionnelle) ou para o BEP (Brevet d'Études Professionnelles). ${ }^{28} \mathrm{Em} 1962$, somente um quarto dos agentes era de origem operária, notadamente nas frações inferiores do serviço público ( $34 \%$ dos agentes da categoria D são filhos de operários). Cf. Xavier BROWAEYS e Paul CHATELAIN, 1984, p. 67.
} 
Já na Alemanha Ocidental, as jovens mulheres sem dificuldades escolares não tardam a entrar na administração para aprenderem uma profissão. Elas possuem um nível de educação geral menos elevado que na França (Mittlere Reife). ${ }^{29}$ As futuras empregadas dos quadros da função pública (Beamte) ${ }^{30}$ que escolheram a carreira de serviço médio não técnico (Laufbahn des nichttechnischen mittleren Dienstes) seguem um treinamento polivalente durante um tempo variável, de três a cinco anos, como "estagiárias". Ao cabo desse período, a administração local lhes propõe uma efetivação ${ }^{31}$ (entre as operadoras de telefone, na metrópole, somente um terço são estatutárias; no interior, são dois terços). Sobretudo no interior, essa escolha profissional era, para as filhas dos notáveis locais (diretor de escola, gerente de uma empresa de mais de cem empregados), uma orientação profissional muito conveniente entre os anos 1950 e início dos anos 1970. Para elas, ao contrário da França, onde o diploma supera a origem social, o acesso a esses empregos significa essencialmente o acesso a "uma situação", ou seja, a um status socioprofissional que corresponde à sua origem social. Assim, ainda que não tenham sido obrigadas a fazê-lo para preservar a segurança de seu emprego, elas não hesitaram em se efetivar, ato essencialmente simbólico.

Com efeito, como já destacaram os trabalhos clássicos sobre a política de educação e organização industrial na França e na Alemanha, ${ }^{32}$ nos anos 1950-70 (período de escolarização das mulheres em questão), a seletividade social no momento da orientação para uma das áreas de formação geral, ou seja, ao término da escola elementar, era de tal forma forte que a área mais nobre do ensino secundário longo na Alemanha (o Gymnasium) estava "de fato praticamente fechada às crianças cujos pais exercem uma profissão manual", ${ }^{33}$ ao contrário da França, onde o ensino secundário se caracterizava por uma grande abertura social. Mesmo crianças de categorias superiores e intermediárias do setor privado sofriam as conseqüências desse fenômeno. Nesse sentido, na Alemanha, a promoção social por meio da aprovação escolar não constituía uma possibilidade. Notadamente para as mulheres, o investimento escolar não era uma estratégia de mobilidade social, nem permitia atingir uma certa estabilidade socioprofissional, como na França. A orientação para o serviço público e o concurso Ihes permitiam apenas manter o status social de origem, independentemente das práticas matrimoniais. Em particular no interior, tratava-se de uma lógica de preservação.

\footnotetext{
${ }^{29}$ Equivalente a dez anos de escolaridade, esse diploma permite o acesso ao colégio (Gymnasium). Contudo, esse diploma constitui o nível que permite tradicionalmente o aprendizado de um ofício. A orientação socioprofissional é efetuada muito cedo na Alemanha: com a idade de dez anos, ao sair da escola elementar (4 anos), os alunos fazem uma opção, seja pelos estudos de ensino geral, mais longos, que conduzem ao Abitur (baccalauréaf), obtido no Gymnasium após 13 anos de estudos, seja por um ensino geral mais reduzido, na Realschule (nível médio), que após dez anos de estudos confere o diploma da Mittlere Reife, seja para a Hauptschule (escola principal, equivalente ao primeiro grau), com uma duração total de oito anos de estudos. A Mittlere Reife pode também ser obtida no Gymnasium; ela é uma possibilidade de recuperação para os alunos com resultados não tão bons, que portanto não irão até o Abitur, para o aprendizado de um ofício em uma Berufsschule (escola profissional que alterna com a aprendizagem em empresa), via menos prestigiosa. Nesse sentido, a orientação socioprofissional para uma profissão de colarinho branco na administração, sobretudo para uma moça, é uma boa alternativa à desqualificação social, por meio da aprendizagem de um ofício manual, que é a conseqüência principal desse nível de estudos.

${ }^{30}$ Carreira que corresponde globalmente ao ingresso no nível $\mathrm{C}$ das carreiras do serviço público na França.

${ }^{31}$ Ou seja, com a condição de se apresentar ao exame de titularização para passar a estatutário, não obrigatório para preservar o emprego. O exame e a titularização não impõem uma mobilidade geográfica, como na França.

${ }^{32}$ MAURICE et al., 1982.

${ }^{33}$ MAURICE et al., 1982, p. 57.
} 
Na Alemanha Oriental, a escolaridade também não parece ser um critério determinante. Com um nível escolar comparável ao das jovens mulheres do Oeste (equivalente a dez anos de estudos), ${ }^{34}$ sua origem social é mais modesta. Os pais são ativos, contrariamente aos do Oeste, e ocupam posições como empregados e operários. Os empregos no serviço público eram uma das raras profissões femininas por aprendizagem disponíveis nessa época: o aprendizado da função de telefonista era certificado por um diploma profissional, o Facharbeiter, reconhecido também por outras empresas. Na exRDA, trabalhar na administração, em uma empresa, em uma coletividade ou junto ao conselho de ministros fazia, certamente, diferença em termos de prestígio social, mas não em termos de estabilidade. ${ }^{35} \mathrm{Na}$ Alemanha - da mesma forma do que na França - as trajetórias de reconversão são, contudo, o tipo de acesso mais freqüente. Para essas mulheres, que tinham ao menos 20 anos no momento de seu ingresso na administração, isso constituiu uma nítida melhora em relação à sua situação socioprofissional anterior. Nascidas durante a guerra, todas são oriundas de famílias monoparentais, ou seja, cresceram sem o pai (filhos de viúvas de guerra, de pais divorciados ou de pai falecido quando ainda jovem). Todas, portanto, começaram a trabalhar precocemente: aquelas oriundas da Alemanha do Oeste possuíam um nível escolar mais elevado, obtiveram seu Mittlere Reife; já as que nasceram na ex-RDA pararam de estudar no final da escolaridade obrigatória, a Volksschule, após oito anos de estudos, embora o nível de escolaridade das mulheres berlinenses fosse geralmente superior ao das mulheres oriundas das zonas rurais. Encontrei essas trajetórias de reconversão exclusivamente na população urbana dos antigos Länder e entre mulheres oriundas da população rural dos novos Länder. Na cidade, onde as possibilidades são a priori mais amplas, esses empregos constituiam uma possibilidade de reconversão para aquelas que desenvolviam outras atividades, em condições de trabalho consideradas penosas; ali, esses empregos permitiam sobretudo que as mulheres recorressem a estratégias de retomada do trabalho, e/ou de autonomia individual, em relação à sua situação pessoal e/ou ao fim de um percurso social marcado pela desqualificação (com ou sem a aquisição do status de funcionária). Para as mulheres originárias de uma zona rural desfavorecida da ex-RDA, a mudança em relação às condições de trabalho degradantes a que estavam sujeitas anteriormente mostrou-se também um fator interveniente, embora as mulheres nem sempre lhe atribuam um status importante. Em comparação com o Oeste, os empregos apresentam um atrativo menor, uma vez que pouco se diferenciam de outros empregos disponíveis pelas condições de exercício da atividade; apenas o conteúdo do trabalho era diferente. De fato, o status dessa atividade parece ser mais baixo do que nos antigos Länder: aquelas que ainda exercem esses empregos atualmente são todas de origem popular.

Resumindo, a comparação das origens socioprofissionais demonstrou uma grande similitude entre os dois (três) países. Em todos os casos, trata-se, por um lado, de um emprego de reconversão (profissional) considerado em razão de seu status, das condições de exercício associadas a ele (na França e em parte na RFA), e, de outro, em razão da natureza do trabalho (na França e na ex-RDA). Todavia, também pode se tratar de uma escolha profissional feita após o término da escola fundamental por causa do status da

\footnotetext{
${ }^{34} \mathrm{Na}$ ex-RDA, o sistema escolar era mais homogêneo que na RFA, distinguindo principalmente entre o diploma que sancionava a Haupt und Oberschule (oito anos de estudos) e a Polytechnische Oberschule (dez anos de estudos).

${ }^{35}$ Também a escassez de mão-de-obra qualificada, o atraso tecnológico e o desprestígio social dos empregos de operadoras e telefonistas da comutação manual faziam com que houvesse facilmente vagas para os cargos de telefonista na ex-RDA.
} 
atividade (na França e na RFA), ou pela ausência de outras possibilidades profissionais 'convenientes' para uma jovem dos anos 1960. Se na França essa orientação recompensa um investimento escolar prolongado, na Alemanha o status social de origem e dos cargos públicos prevalece na orientação mais precoce para a aprendizagem da função de telefonista. Em todos os casos, trata-se de uma orientação socioprofissional que abre para as mulheres espaços de liberdade e margens de ação flexíveis para conduzir sua trajetória socioprofissional ulterior.

\section{Universo profissional e extraprofissional: a relação entre as trajetórias profissionais e familiares}

A despeito da relativa similitude do status dos empregos no serviço público na França e na Alemanha, é a análise das trajetórias socioprofissionais das operadoras que permite evidenciar a forma como esses empregos contribuem para as diferenças de status da atividade feminina nesses países. De fato, mesmo que a maioria das operadoras quase não faça uma carreira profissional no sentido próprio do termo, ou seja, de forma ascendente, a comparação das trajetórias nos dois países permite mostrar uma maior integração das fronteiras entre o universo profissional e extraprofissional na França, ao contrário da Alemanha. A análise das carreiras socioprofissionais das mulheres confirma essa hipótese e mostra os limites das duas (três) práticas nacionais: a partir de uma primeira tipificação de quatro casos por país, é a comparação internacional da construção societal das carreiras ascendentes - explicitada a partir da análise de um exemplo empírico emblemático por país - que permite realçar o status diferente da atividade nos dois (três) países, em particular em relação ao peso da situação familiar.

Conforme mencionado na introdução, a escolha da amostra não tem qualquer pretensão de ser representativa do conjunto dos empregados administrativos subalternos, nem dos correios e/ou das telecomunicações. Meu objetivo era ter dar conta de uma grande diversidade de situações.

Como estudante, procedi, essencialmente, à ampliação das relações iniciais estabelecidas com o campo (efeito 'bola de neve'). Além disso, foi por meio de relações pessoais que tomei conhecimento das primeiras tentativas de reorganização interna dos correios alemães em 1994/95, na chegada da privatização parcial. É também por essa via (de relações iniciais com o meio) que obtive um contrato de trabalho por tempo determinado com a operadora francesa (por intermédio da responsável pelo centro de informações parisiense que me foi apresentada por um antigo chefe do centro, hoje aposentado, que eu entrevistara).

Na França, as oportunidades de campo foram mais variadas do que na Alemanha e foram se multiplicando com o estabelecimento de contatos mais pessoais na empresa, com os gestores e também com as operadoras e a chefia quando em visitas ao interior. Foi por essa via que escolhi as pessoas entrevistadas, assim como a partir da análise das interações observadas diretamente entre o pessoal operador e a chefia. Na França, meu estatuto de pesquisadora Cifre (Convention industrielle de formation par la recherche - Convenção industrial de formação por pesquisa) colocava-me ao abrigo das tentativas de meus superiores hierárquicos de se servirem de minha posição, ao mesmo tempo interna e externa à empresa 
(em razão da obrigação de realização da tese), para, por exemplo, promover as formas de reorganização do trabalho e o desvio de meu campo de pesquisa. Na Alemanha, o acesso obtido à empresa por intermédio dos sindicatos (Deutsche Postgewerkschaff) foi se fechando progressivamente com o avanço da privatização e a entrada em vigor da concorrência. Mesmo assim, pude contar com algumas reaberturas pontuais, por meio de relações bilaterais entre as duas empresas nacionais (no âmbito de uma joint venture temporário, chamado Global One).

As entrevistas foram realizadas individualmente e, salvo poucas exceções, no local de trabalho, em uma sala separada (destinada às reuniões sindicais ou dos funcionários, assim como na sala de descanso). Elas versam sobre toda a trajetória social e profissional da pessoa entrevistada. Além das transformações da vida profissional, foi dada uma atenção particular à interação com a vida familiar (mudanças da situação familiar, como casamentos, separações, falecimentos, nascimentos, a carreira do cônjuge, a educação das crianças ou a intervenção de outros membros da família). A tipificação das trajetórias apresentada a seguir corresponde a um esforço de clarificação e de análise dos resultados para fins de exposição, ou seja, a uma tentativa de formar grupos de tamanho desigual entre o conjunto da população entrevistada por país (cf. Quadros 2, 3 e 4), mas um tanto homogêneos, considerando-se um certo número de critérios, como o estado civil e a situação familiar, a origem social e a situação socioprofissional atual (posição social e profissional do marido), a origem geográfica (interior/ zona urbana), o modo de vida e a relação com o trabalho e o emprego. 0 objetivo principal era chegar a um certo nível de inteligibilidade dos resultados. Visto que a maioria das trajetórias das operadoras se desenrola no mesmo nível hierárquico (o objeto da tipificação da primeira subparte), escolhi apresentar alguns resultados empíricos de carreiras ascendentes minoritárias (um exemplo por contexto societal, mais significativo em termos da comparação internacional, objeto da segunda subparte): hoje, assim como ontem, nesses níveis sociais intermediários, o peso da situação familiar cria o desvio do comportamento de atividade das mulheres entre os dois países tão semelhantes.

\section{Carreiras horizontais: quatro casos-tipo dentro de seu respectivo contexto societal}

Na França, as mulheres que fizeram uma carreira horizontal foram promovidas por antiguidade dentro da escala inicial do serviço público, incluindo-se aí a maior parte do tempo para chegar ao grau de "controlador" (e sem exercer funções diferentes). Ativas durante toda a vida, elas, no entanto, alternaram muitas vezes períodos de interrupção do trabalho ("licença"). Em sua maioria, elas são (ou foram) casadas e possuem filhos. Seus cônjuges, em grande parte, estão no serviço público, nos EPIC (estabelecimento público industrial ou comercial) ou fizeram carreira em grandes empresas nacionais. ${ }^{36} \mathrm{Se}$ no momento do casamento eles não possuíam uma origem social superior à da esposa, em grande parte tiveram uma ascensão social por meio de uma promoção profissional.

\footnotetext{
${ }^{36}$ Essas empresas também permitem a seus empregados uma mobilidade geográfica em todo o território nacional.
} 
Para o conjunto das mulheres que permaneceram em empregos subalternos, sem mobilidade hierárquica, o exercício da atividade profissional ocupa um lugar importante em sua vida, sobretudo em termos de sociabilidade fora do âmbito doméstico.

Entretanto, na análise das trajetórias socioprofissionais e da construção da relação com o emprego das mulheres, interesso-me mais pelos aspectos relativos à mobilidade social. Assim, o valor que elas atribuem à atividade profissional é indissociável do modo de vida proporcionado ao casal: a atividade profissional pode possibilitar uma ascensão social.

O modo de interação entre as trajetórias socioprofissionais do casal fundamenta a mobilidade social ascendente da família: no primeiro caso-tipo, a atividade profissional da mulher é cadenciada pela carreira masculina. Assim, a mobilidade geográfica da esposa (após transferências e/ou "licenças", concedidas aos estatutários e aos auxiliares em certos períodos) é geralmente motivada pela mobilidade geográfica obrigatória de seu cônjuge, condição de sua promoção. Contudo, em um segundo caso-tipo, os dois cônjuges possuem uma origem similar (filho de agricultor do Ministério e filha de um casal de comerciantes de Côtes du Nord), e a mulher é o motor da mobilidade social do casal, por meio de sua relação com o trabalho e o emprego: uma relação de emprego extremamente estável associa-se à mobilização das vantagens que o emprego proporciona segundo as prioridades da vida familiar, como a escolha da localização geográfica do trabalho. Nesse caso, o casal utiliza as vantagens associadas ao estatuto do serviço público para adotar um modo de vida orientado em função das relações familiares e não da carreira profissional de um ou de outro membro do casal. Ambos empreendem, então, uma trajetória profissional horizontal e uma vida de casal cadenciada pelos acontecimentos extraprofissionais. A mobilização das condições de trabalho, portanto, gira em torno desse projeto de vida.

No terceiro caso-tipo, o estatuto do emprego permite evitar os riscos de uma prática de mobilidade social que gira em torno da carreira do cônjuge: a segurança do emprego limita a dependência da mulher (ou do homem) em relação ao cônjuge, mesmo que ela pare temporariamente de trabalhar ("licença"). Esse estatuto pode permitir a preservação de uma forma de autonomia e/ou assegurar a manutenção de um certo nível de vida após a perda do cônjuge (falecimento ou separação). No quarto caso-tipo, muito similar ao precedente, o estatuto do emprego e as garantias que ele proporciona são valorizados através de uma nova ligação matrimonial. O status de funcionário permite, ao longo de toda a trajetória, redefinições do projeto de vida do casal ou do/a estatutário/a.

Assim, na França, a relação com o emprego só pode ser entendida se considerarmos a maneira como as mulheres utilizam a estabilidade do emprego e as outras vantagens estatutárias para realizar seu projeto de vida e de mobilidade social.

Na Alemanha, pude também distinguir quatro tipos de trajetórias femininas, notadamente em função de seu status matrimonial e de sua origem geográfica. O primeiro caso-tipo concerne às mulheres casadas que permaneceram no nível inferior da escala. Sua união matrimonial não Ihes proporciona uma mobilidade social ascendente destacável, ao contrário da França. Em um caso emblemático desse grupo, a origem social da esposa é superior à do cônjuge, que ocupa entretanto uma posição profissional superior à dela. A integração dessa mulher originária da RFA no mercado de trabalho é parcial, inspirada em uma estratégia familiar. Ela conta com uma certa promoção por antiguidade, mas em um ritmo moderado em razão de sua integração parcial ao mercado de emprego. Com efeito, ela retomou o trabalho em jornada parcial após parar de trabalhar durante certo tempo, itinerário típico das mulheres casadas com filho na RFA ${ }^{37}$

${ }^{37}$ De uma maneira geral, na RFA, a taxa de atividade das mulheres casadas e sem filhos é de $82,6 \%$, de $57,8 \%$ a das que têm um filho e de $47,7 \%$ das que têm dois (Cf. resultados do Mikrozensus de 1991 , 
(a duração máxima da "licença" concedida aos estatutários, nos anos 1980, era de 12 anos, ou seja, para afastamento sem vencimentos). Contudo, as mulheres, nesse primeiro caso, dispõem de habilidades diferentes daquelas das operadoras em início de carreira: seu investimento profissional é significativo, sem que seja recompensado por uma promoção.

Um segundo tipo de trajetória de mulheres alemãs se caracteriza por sua chegada tardia à atividade, após um percurso de reconversão profissional: em um caso, trata-se de uma mulher divorciada e casada em segundas núpcias com um homem de origem social inferior (um operário que também trabalha na administração dos correios e telecomunicações). Como outras mulheres desse grupo, que também são divorciadas ou viúvas ainda jovens, e apesar da ausência de uma carreira profissional ascendente, ela estabeleceu uma relação de trabalho extremamente positiva, sobretudo em razão das relações de sociabilidade que foram estabelecidas no trabalho. De uma maneira geral, essa relação com o trabalho corresponde a um período de estabilização socioprofissional. Elas são todas envolvidas profissionalmente. As mulheres que vivem na parte situada a oeste de Berlin têm, contudo, uma vida extraprofissional importante, ligada em parte às relações estabelecidas no trabalho.

Trata-se, com efeito, de um subgrupo do tipo precedente: o trabalho no serviço de auxílio à lista assegura às mulheres dos antigos Länder, e mais particularmente de Berlin, uma nova independência. De fato, encontrei um certo número de mulheres de perfil comparável, para as quais a conquista de uma atividade estável coincide com a retomada da autonomia (freqüentemente após um período familiar de interrupção da atividade), com ou sem um novo cônjuge. Essas mulheres se caracterizam pela importância que conferem à sua vida extraprofissional, que se tornou possível pela liberdade de escolha dos horários de trabalho, assim como pela segurança material que o emprego thes proporciona. Elas preferem horários tardios (à noite), a fim de poderem contar com o dia para outras atividades. Assim, a possibilidade de obter dias livres em troca de trabalho no fim de semana era para elas uma vantagem importante, pois isso Ihes permitia viajar muito. A sociabilidade com os colegas de trabalho, e fora dele, ocupa um lugar importante em suas representações acerca da atividade (elas se encontram regularmente à noite, no café em frente ao central de atendimento). Os horários de trabalho em comum thes permitem notadamente formar um coletivo e estabelecer relações privilegiadas. Assim, para elas, o estatuto do emprego se soma à satisfação de um certo modo de vida.

Um quarto grupo compreende as mulheres vindas dos novos Länder, que vivem nas regiões rurais. Embora as operadoras não tenham promoção, elas investem fortemente no trabalho. Sua vida é construída em torno de sua atividade profissional, que era um lugar de sociabilidade e de atividades comuns importantes, sobretudo antes da reunificação. Essas mulheres mostram-se muito ligadas ao exercício de sua atividade e à sua continuidade. $O$ status social de sua atividade foi também revalorizado em virtude do aumento do desemprego das mulheres nos antigos Länder após a reunificação e em razão da situação precária das mulheres sozinhas e das famílias monoparentais. ${ }^{38}$

Arbeitsmarktreport für Frauen, 1994, p. 18). Na Alemanha, cerca de $60 \%$ das mulheres de 22 a 60 anos interrogadas em 1990 pelo dispositivo de pesquisas da CEE deixam o emprego após o primeiro filho. Cf. Marianne KEMPENEERS e Eva LELIEVRE, 1993, p. 89. As retomadas, com freqüência, ocorrem em empregos de meio período (Cf. MARRY et al., 1998, p. 359).

${ }^{38}$ Os empregados do antigo Post Ost (administração do correio da ex-RDA) foram integrados na Deutsche Bundespost (DBP - correio da Alemanha reunificada) quando da reunificação. Não sendo estatutários, eles obtiveram uma estabilidade de emprego comparavel à dos empregados da $D B P$. 


\section{As carreiras profissionais ascendentes: um exemplo significativo das diferenças sociais}

Vimos, até aqui, que existe uma similitude apenas relativa tanto nas origens como nas trajetórias socioprofissionais das mulheres na França e na Alemanha. Ficou evidente que esses empregos do serviço público constituem, sobretudo na França, o termo de uma escolaridade prolongada. A ancoragem das mulheres no mundo do trabalho é ali também mais forte: na França, os domínios do universo profissional e extraprofissional estão mais estreitamente ligados, notadamente por meio da mobilidade social articulada às carreiras dos cônjuges. Nesse contexto, mostram-se centrais as formas como as mulheres jogam com a mobilidade geográfica, uma particularidade da função pública francesa.

Em contrapartida, profundas diferenças referentes à relação de emprego das mulheres nos três países aparecem quando analisamos algumas carreiras profissionais. As carreiras ascendentes - ainda que sejam exceções na amostra entrevistada - são sintomáticas do comportamento de atividade das mulheres e do status da atividade profissional na França e na Alemanha, como ilustrarei com um exemplo-tipo por país. De uma maneira geral, ainda que os casos de ascensão hierárquica constituam a exceção, na França as mulheres podem atingir níveis superiores (na França: nível chefe de centro; na Alemanha: nível de supervisão).

O primeiro caso-tipo é o de uma mulher francesa, Nadine, que fez uma carreira passando pelo menos temporariamente pelo senviço de auxílio à lista, onde foi entrevistada; é casada e tem filhos. Como as mulheres que permaneceram no mesmo nível hierárquico, ela é casada com um funcionário. Em contrapartida, como seu esposo ocupava um nível superior ao seu no momento do casamento, e não realiza uma carreira ascensional (que implica poucas transferências obrigatórias), ela conta com condições de exercício desses empregos de status inferior (escolha da localização do emprego, horários) para realizar sua promoção profissional. As licenças-maternidade lhe proporcionam uma possibilidade suplementar para adquirir conhecimentos: os nascimentos dos filhos (três) e os concursos encadeiam-se.

Assim, Nadine, nascida em 1953 em Lyon, órfã, estava no primeiro ano de Direito na Faculdade de Lyon no momento em que ingressou como auxiliar nos P.T.T. no setor de cheques postais para financiar seus estudos. Ela se casou no mesmo ano, aos 19 anos, em 1972, com um professor do ensino secundário originário da África do Norte. Ela é nomeada operadora de interurbano em Paris. Os nascimentos de seus dois primeiros filhos são próximos (1972 e 74) e ela trabalha à noite para poder cuidar deles com o marido, enquanto se prepara para o concurso de inspetor. Aos 26 anos, em 1977, ela foi nomeada para um agência de correio, onde integra uma equipe de carteiros e faz a triagem do correio e o atendimento de reclamações de clientes. Ao mesmo tempo, ela segue um curso de formação permanente para preparar o concurso para inspetor principal, o próximo nível hierárquico. Aos 30 anos, após ter passado no concurso, torna-se gerente de uma pequena agência de correio (um posto), momento do nascimento de seu terceiro filho. Aos 34 anos, obtém um afastamento da administração para passar dois anos na ENA (École Nationale d'Administration), período após o qual a família se muda para a cidade de Pau, no Sul da França, onde ela foi nomeada para a direção dos organismos territoriais. Dois anos mais tarde, seu marido é transferido para Paris. Ela requer sua reintegração à administração dos P.T.T. e é nomeada para a direção no centro de comutação em 1991, onde ela havia iniciado, transformado depois em centro de auxílio à lista. ${ }^{39}$ Após o fechamento desse centro, foi realocada com uma parte dos empregados em um outro centro de auxílio à lista e tornou-se chefe de centro em 1994.

\footnotetext{
${ }^{39}$ Somente dois ou três centros de auxílio à lista (do conjunto de cerca de uma centena de centros franceses no total) têm um responsável feminino (o nível hierárquico mais alto de um centro).
} 
Essa carreira excepcional baseia-se em uma relação com o emprego extremamente sólida e na forma como essa mulher contorna os elementos que poderiam se opor à sua realização profissional, como o nascimento dos filhos ou a diferença social com seu cônjuge. Ambos utilizam as vantagens que esses empregos proporcionam, de maneira a conciliar a atividade contínua do cônjuge e a carreira da esposa. Além disso, essa antiga operadora goza plenamente das possibilidades de mobilidade do serviço público, inclusive entre as diferentes administrações. É preciso notar, contudo, que o investimento de Nadine em sua atividade profissional é muito importante em comparação com uma carreira que poderia ter sido mais claramente ascensional.

Na Alemanha, embora a ascensão hierárquica seja pouco importante nas duas partes (somente até o nível do enquadramento imediato), as diferenças entre os antigos e os novos Länder são fundamentais: na RFA, os supervisores são mulheres solteiras, que se orientaram para a carreira ao término de sua escolaridade, enquanto na ex-RDA são mulheres casadas, com filho(s). Além do mais, na Alemanha Ocidental, observa-se um superinvestimento no trabalho.

Assim, o caso de Ingrid, originária dos antigos Länder, ilustra bem esse primeiro caso-tipo. Ela tem uma relação com o trabalho positiva e investe fortemente no nível profissional, em particular na área técnica (cursos de informática para as operadoras). Por outro lado, transitou por outros serviços que demandavam habilidades suplementares, como o centro de auxílio à lista internacional. A trajetória dessa supervisora (Aufsicht) demonstra como essa promoção, bem pouco ascensional, demanda o cumprimento de uma larga gama de tarefas não reconhecidas. Para beneficiar-se de uma promoção hierárquica, precisa-se de uma mudança de serviço e/ou pelo menos de função. ${ }^{40}$ Entretanto, o fraco rendimento profissional vai de par com condições de trabalho vantajosas (a importância do tempo livre, por exemplo), que o compensam.

Aos 27 anos, em 1964, dois anos após a sua efetivação, Ingrid é promovida por antiguidade ao nível de secretária do serviço telefônico (Fernmeldesekretärin) e aos 32 anos, em 1969, ao grau de secretária-chefe do serviço telefônico (Fernmeldeobersekretärin), o próximo nível da carreira administrativa do serviço não-técnico, em razão de sua "particular aptidão" (o domínio do inglês). Ela foi transferida para o serviço de comutação internacional no mesmo ano.Em 1970, esse centro fecha e ela opta pelo serviço de informações em razão dos horários de trabalho. Ela obtém a promoção para o grau de secretária principal (Hauptsekretärin) no mesmo ano e ocupa funções de supervisão a partir de 1972 (aos 35 anos) nesse centro, o que corresponde ao seu tífulo administrativo na escala hierárquica da administração. Em 1987, aos 50 anos, no momento da introdução da informática no centro de auxílio à lista, ela faz diversos cursos e treina outras operadoras. Em 1996 (aos 59 anos), é encarregada do sistema informático do centro. Ela sempre trabalhou em tempo integral e mora na casa da mãe. Fora do trabalho, ela faz jardinagem.

Essa antiga operadora soube tirar proveito das poucas possibilidades de diversificação que se Ihe apresentaram no início da carreira. Ela ilustra a possibilidade de fazer uma carreira sem mobilidade geográfica, mas à condição de saber aproveitar as raras ocasiões de diversificar a atividade, que se apresentam nesse universo restrito, de preferência no início da carreira.

\footnotetext{
${ }^{40} \mathrm{Na}$ RFA, o sistema de promoção sempre se baseou em grande parte no princípio da cooptação para a chefia intermediária (supervisão) e os chefes de centro. Interrogados sobre seus critérios de avaliação, estes mencionaram em particular o "comportamento" das pessoas a serem promovidas. Assim, além do cumprimento de tarefas suplementares, elementos como pontualidade e "boa vontade" foram mencionados.
} 
Em contrapartida, como se ilustra, a título de exemplo, com o caso de Kerstin, as operadoras originárias da ex-RDA parecem obter sua promoção ao título e ao posto efetivo de supervisora com menos dificuldades que as mulheres na RFA. De fato, Kerstin não parece demonstrar uma habilidade diferente das outras operadoras, nem um investimento no trabalho particular, ao contrário de Ingrid. Ela faz parte dos poucos que conseguiram alguma vantagem com a reunificação: ${ }^{41}$ foi promovida dentro do contexto da fusão, em 1990, da administração do correio da Alemanha Ocidental (DBP - Deutsche Bundespost) para o serviço do correio da Alemanha Oriental (Deutsche Post Ost).

Aos 19 anos, em 1978, um ano após seu diploma profissional (Facharbeiter) no centro de comutação de Francfort sur Oder, Kerstin casa-se com um contramestre que trabalha na indústria metalúrgica. Ela tem seu filho e pára de trabalhar, porque não encontra vaga na creche. Aos $21 / 22$ anos, em 1980/81, ela retoma seu trabalho em tempo integral no centro de comutação interurbano (Fernamf). Em 1989/90, com 30 ou 31 anos, após a reunificação, ela postula e obtém um cargo de supervisora no centro de auxílio à lista, mas se considera muito jovem para se fazer respeitar. ${ }^{42}$ Tentou ser transferida, mas não conseguiu. $O$ posto lhe foi negado aos 25 anos, em 1984, porque ela se recusara a aderir ao sindicato da amizade russo-alemã (SDF - sowjetisch-deutsche Freundschaft). Em 1991, seu marido licencia-se, mas segue uma formação em eletrônica e retoma o trabalho como instalador de linhas. Aos 37 anos, em 1996, ela é supervisora e trabalha em tempo integral, embora deseje trabalhar meio período, mas não o faz por razões financeiras (o casal acaba de comprar uma casa).

O status social desses empregos mudou completamente desde a reunificação: antes, esse trabalho improdutivo era desconsiderado, inclusive para uma mulher; depois, tornouse um privilegio. Kerstin beneficia-se de segurança de emprego igual à dos empregados da $D B P$ (quase igual aos estatutários). Ao mesmo tempo em que ela é promovida, seu marido, um antigo contramestre, se vê temporariamente desempregado. Após um rebaixamento a uma reconversão profissional (ele faz um trabalho de execução), encontra trabalho. A hierarquia dos status sociais dos empregos dos dois membros do casal inverteuse.

\section{Algumas notas comparativas à guisa de conclusão: o papel social dos empregos subalternos da função pública}

Na França, ao contrário da Alemanha, o status dos empregos subalternos do serviço público e a utilização que deles fazem as mulheres possibilitam, de um lado, mobilidade social por meio das trajetórias do casal e, de outro, associar a carreira profissional à vida familiar. Essas duas características explicam como esses empregos públicos contribuíram, na França, para uma fixação mais forte e mais precoce das mulheres à condição assalariada.

\footnotetext{
${ }^{41} O$ período que se seguiu à reunificação, durante o qual as mulheres foram promovidas, caracteriza-se por uma importante alta do desemprego na ex-RDA, em particular entre as mulheres. Assim, em julho de 1993, a taxa oficial de desemprego é de $15,1 \%$ (o que corresponde a 1,1 milhão de pessoas declaradas), da qual $64,4 \%$ de mulheres. No mesmo período, o total da população ativa passou de 9,2 milhões de pessoas em setembro de 1989 (um mês antes da queda do muro) para à 6, 1 milhões em julho de 1993. Cf. QUACK e MAIER, 1994, p. 1266.

${ }^{42}$ Cerca da metade das pessoas que trabalham nesse centro (50) já trabalhou à época da RDA. Segundo Kerstin, elas são muito idosas para aceitar mudar de serviço. Por outro lado, as transferências são difíceis de serem obtidas, porque os cargos muitas vezes já foram atribuídos oficiosamente, apesar do processo seletivo publicado pela direção regional.
} 
De fato, a opção das mulheres pelos empregos do serviço público, na França e na Alemanha, obedece a lógicas muito diferentes, que só podem ser compreendidas se for considerado o conjunto de possibilidades que Ihes são oferecidas. Assim, na França, o ingresso na função pública constitui uma maneira interessante de valorizar um diploma relativamente elevado, sobretudo para mulheres de origem modesta. De acordo com o tipo de associação matrimonial (ou seja, conforme a diferença social entre os cônjuges) e suas respectivas ambições profissionais, esses empregos do serviço público permitem uma grande variedade de interações entre as trajetórias socioprofissionais dos dois membros do casal. Todas as situações mostram-se possíveis nos casos-tipo, incluindo uma carreira profissional da esposa. Efetivamente, esses empregos se caracterizam pela amplitude de possibilidades que oferecem às mulheres, em termos de trajetória socioprofissional e de redefinição do seu projeto de vida. A diferença decisiva em face da Alemanha reside, contudo, no fato de que, na França, esses empregos deram lugar a uma redistribuição de papéis do casal, que permitiu uma transformação do comportamento da atividade feminina.

Na Alemanha, o universo de possibilidades oferecido às mulheres apresenta-se de uma forma bastante diversa. Os empregos respondem, ali, a uma preocupação sobretudo voltada à segurança: seja para preservar o status social de origem, também dentro de uma associação matrimonial, seja para assegurar uma fonte de renda para as mulheres que conheceram a miséria e o abandono parental em sua juventude.

Como a aliança matrimonial não cumpre efetivamente a mesma função de mobilidade social que na França, e sempre comporta riscos eventuais, o ingresso no serviço público representa em todos os casos uma boa possibilidade de preservar uma certa autonomia, sem contudo impedir a realização de um projeto familiar. Em comparação com a França, isso se revela também no fato de que o rendimento do diploma parece ser, para uma mulher alemã, menos evidente no mercado de trabalho nacional, mais aberto às qualificações "técnicas" detidas pelos homens. Dada a diferença do papel do diploma para uma mulher na Alemanha, modifica-se também o valor relativo de um emprego do serviço público, mesmo que esse se situe na base da escala hierárquica. $\mathrm{Na}$ ex-RDA, esses empregos femininos acessíveis pela aprendizagem não se diferenciam dos demais senão por um status social relativamente desvalorizado, visto não serem produtivos.

Em resumo, a diferença nos modos de integração das mulheres no mundo assalariado, nos três países, repousa em seu grau de flexibilidade. De fato, essa característica é particularmente adaptada à construção social do assalariamento da população feminina durante o período estudado: a disponibilidade profissional é variável, no espaço e no tempo.

As relações com o emprego das mulheres da ex-RDA e da França, assim como o status da atividade feminina, se parecem mais aos das mulheres do Oeste alemão, com uma nuance: na França, esses empregos possibilitaram trajetórias sociais ascendentes a casais de funcionários, o que não ocorreu no caso das mulheres do Leste alemão. Entretanto, na ex-RDA e na França, o Estado contribuiu fortemente para a criação de condições para uma generalização mais precoce e mais ampla de uma atividade profissional contínua das mulheres do que na RFA. Na ex-RDA, a intervenção do Estado refere-se sobretudo a possibilidades de guarda dos filhos e, de forma mais geral, à integração do papel de mãe-de-família das mulheres na organização do trabalho. Na França, ela diz respeito também à guarda dos filhos, mas a ancoragem das mulheres no mundo de trabalho passou nesses empregos sobretudo pela utilização, por parte de casais de funcionários, das condições de exercício dos empregos do serviço público. 


\section{Referências bibliográficas}

ALTER, Norbert; REYNAUD, Emmanuèle. Analyse sociologique de la réforme de France Télécom volet social de la réforme: les reclassifications. CEE, mars 1995. Note de synthèse. $19 \mathrm{p}$.

Arbeitsmarktreport für Frauen. Bundes anstalt für Arbeit, Nürnberg, janvier 1994.

BATTAGLIOLA, Françoise. Histoire du travail des femmes. La Découverte, Paris, 2000. 123 p. BROWAEYS, Xavier; CHATELAIN, Paul. Les France du travail. PUF, Paris, 1984. 267 p.

BUSCATTO, Marie. "Les centres d'appels, usines modernes? Les rationalisations paradoxales de la relation téléphonique". Sociologie du Travail, n. 44, p. 99-117, 2002.

COUSIN, Olivier. "Les ambivalences du travail. Les salariés peu qualifiés dans les centres d'appel". Sociologie du Travail, n. 4, v. 44, p. 499-520, 2002.

FLICHY, Patrice; ZARIFIAN, Philippe (Coord.). "Les centres d'appel". Reseaux, n. 1 14/2002.

GEORGES, Isabel. Travail et trajectoires de femmes dans des emplois de télécommunications en France et en Allemagne. Thèse de doctorat de Sociologie, sous la direction de Margaret Maruani, Université Paris VIII, 2000a. 642 p.

. "Les définitions sociales de la productivité. Les opératrices des renseignements téléphoniques". Cahiers du Centre de Recherches Historiques, n. 25, p. 67-80, octobre 2000b.

"Les emplois d'exécution dans les télécommunications: comparaisons FranceAllemagne". Travail, Genre et Sociétés, n. 6, p. 143-164, 2001.

GRAFMEYER, Yves. "Les employés de la Société Lyonnaise de Banque: carrières professionnelles et mobilité géographique dans une entreprise de réseau". In: LEQUIN, Yves (éd.). L'usine et le bureau. PUL, Lyon, 1990. 193 p.

. Les gens de la banque. PUF, Paris, 1992. 283 p.

Handelsblatt du 28 septembre 1999.

KEMPENEERS, Marianne; LELIEVRE, Eva. "Women's work in the EC: five career profiles". European Journal of Population, n. 9, p. 77-92, 1993.

MARRY, Catherine; KIEFFER, Annick; BRAUNS, Hildegard. "France-Allemagne: inégale avancées des femmes. Évolutions comparées de l'éducation et de l'activité des femmes de 1971 à 1991". Revue Française de Sociologie, XXXIX-2, p. 353-389, avril/juin 1998.

MARUANI, Margaret. "Statut social et modes d'emplois". Revue Française de Sociologie, n. 1, p. 31-39, 1989.

. "Les inégalités professionnelles hommes-femmes sont devenues plus injustes". Le Monde, p. 16, mardi, 28 mars 2000.

MARUANI, Margaret; REYNAUD, Emmanuèle. Sociologie de l'emploi. La Découverte, Paris, 1993. Coll. Repères. $126 \mathrm{p}$.

MAURICE, Marc; SELLIER, François; SILVESTRE, Jean-Jacques. Politique d'éducation et organisation industrielle en France et en Allemagne. PUF, Paris, 1982. 382 p.

QUACK, Sigrid; MAIER, Friederike "From State Socialism to Market Economy-Women's Employment in East Germany." Environment and Planning, A, v. 26, 1994, p. 12571276.

REYNAUD, Emmanuèle; REYNAUD, Jean-Daniel; MERCIER, Nicole. Les réformes de 1990 à France-Télécom. CNAM - LERPSO, juin 1991. 78 p.

[Recebido em outubro de 2003 e aceito para publicação em abril de 2004] 


\section{Executing Jobs in Telecommunications: Comparing France and Germany}

Abstract: This comparative study between France and Germany handles with transformations and continuities of female employment in the two countries since the 1960s, based on an analysis of low-level jobs in the public sector. The social status of female employment is still different in these otherwise similar European countries: unlike in France, being married and having children in Germany continues to create a gap between women with continuous employment and those without. Starting from this general assessment, this article aims at analyzing the extent to which jobs in the public sector, as well as the practices of women in these jobs, influence this tendency. In this context, the social function of a particular type of employment, considered as a prototype of a poorly qualified female occupation - telephone inquiry services - will be analyzed more closely, based on a qualitative analysis of the relation to work and employment of these telephone operators.

Key words: women's labour, subaltern employment, public sector, international comparison (France-Germany).

Tradução de Carmem C. O. Cacciacarro 